\title{
First fossil of Cylindrostethinae (Heteroptera: Gerromorpha: Gerridae) in the Paleocene of Menat, France
}

\author{
Viktor Hartung, Romain Garrouste, Jean-Marc Pouillon, and André Nel
}

\begin{abstract}
Cylindrostethus gaudanti sp. nov., first fossil representative of the gerrid Cylindrostethinae, is described from the Paleocene of Menat (Centre of France). It is very modern in appearance, and its characters are sufficiently preserved to permit specific identification into the genus Cylindrostethus. Its presence in the European Paleogene suggests that this subfamily is very ancient, in accordance with its present disjunct tropicopolitan distribution. The modern Cylindrostethinae are restricted to the tropical rainforests, in accordance with the similar palaeoenvironment of the Menat ancient lake. Possible sexual dimorphic trait in the length of the fore femora is described for the new species.
\end{abstract}

Viktor Hartung. Staatliches Museum für Naturkunde Karslruhe, Erbprinzenstrasse 13; D-76133 Karlsruhe, Germany. viktor.hartung@smnk.de

Romain Garrouste. Institut de Systématique, Évolution, Biodiversité, ISYEB - UMR 7205 - CNRS, MNHN, UPMC, EPHE, Muséum national d'Histoire naturelle, Sorbonne Universités, 57 rue Cuvier, CP 50,

Entomologie, F-75005, Paris, France. e-mail: garroust@mnhn.fr

Jean-Marc Pouillon. 179 rue des Plattieres, F-38300 Nivolas Vermelle, France. jmpdb@wanadoo.fr André Nel. Institut de Systématique, Évolution, Biodiversité, ISYEB - UMR 7205 - CNRS, MNHN, UPMC, EPHE, Muséum national d'Histoire naturelle, Sorbonne Universités, 57 rue Cuvier, CP 50, Entomologie, F75005, Paris, France. anel@mnhn.fr Corresponding author

Keywords: Insecta; water strider; new species; first fossil record

Submission: 27 January 2016 Acceptance: 25 July 2016

\section{INTRODUCTION}

The fossil record of the Gerridae is not as rich, as could be expected from a semiaquatic family, but this corresponds to a general situation for the aquatic and semiaquatic insects, compared to the fossil record of terrestrial insects. The oldest fossil is dated from Late Albian amber (Perrichot et al.,
2005). Nevertheless the representatives of this family are among the gerromorphans that can be readily recognized even in compression fossils (Damgaard et al., 2014). Thus, quite a few representatives from various subfamilies have been described: Gerrinae (see overview in Damgaard, 2008a; Damgaard et al., 2014), Halobatinae (Andersen, 1998), Charmatometrinae (Andersen,

http://zoobank.org/830976AF-32EF-4483-A064-0E9557B37D98

Hartung, Viktor, Garrouste, Romain, Pouillon, Jean-Marc, and Nel, André. 2016. First fossil of Cylindrostethinae (Heteroptera: Gerromorpha: Gerridae) in the Paleocene of Menat, France . Palaeontologia Electronica 19.3.33A: 1-10

palaeo-electronica.org/content/2016/1568-paleocene-gerridae-from-france 
2000) and Electrobatinae that are only known from Dominican amber (Andersen and Poinar, 1992; Andersen, 2000). Fossils of the Cylindrostethinae have not been known yet, although the Eocene Messel genus Cylindrobates incertae sedis could have affinities to the extant Cylindrostethus (Wappler and Andersen, 2004). Here, we describe a fossil from the Paleocene of Menat (France) that is attributable to Cylindrostethus following the key of Andersen (1982) and thus could be considered the first fossil representative of this subfamily and one of the oldest known Gerridae, after the Cretaceous Cretogerris albianus Perrichot et al., 2005.

\section{MATERIAL AND METHODS}

Preparation was made using a compressed air needle. The specimens were examined under a Nikon SZ10 stereomicroscope. Photos were taken with an Olympus E-3 digital camera. Several digital pictures were reconstructed using Helicon Focus and Adobe Photoshop. SEM microphotographs of the setae were taken with the Environmental SEM of the Muséum national d'Histoire naturelle Paris (MNHN) Collection Department, using the mode BSE. All measurements are given in millimetres. Materials with the labels MNHN are stored in the Laboratory of Palaeontology, Muséum national d'Histoire naturelle, Paris, France. Material with the label MNT is stored in the collection of the town of Menat. The fossils from Menat are preserved as compressions in organic-rich spongo-diatomites, which were deposited in a former small maar lake, currently dated to about $56 \mathrm{Ma}$ (Palaeocene) (Vincent et al., 1977; Michon, 2000; Michon and Merle, 2001). It is also well known for the exceptional preservation of the flora and fauna (Piton, 1940; Wappler et al., 2009). This outcrop is very rich in fossil terrestrial insects, mainly beetles (Curculionoidea, Buprestidae, Cerambycidae, Cupedidae, etc.), Blattodea, and Hemiptera, mainly Heteroptera Pentatomorpha. Aquatic insects are very rare, mainly belonging to the presently described species, even if a Gyrinidae is recorded.

\section{SYSTEMATIC PALAEONTOLOGY}

Infraorder GERROMORPHA Popov, 1971

Family GERRIDAE Leach, 1815

Subfamily CYLINDROSTETHINAE Matsuda, 1960

Genus CYLINDROSTETHUS Mayr, 1865

Cylindrostethus gaudanti sp. nov.

Figures 1-6, Table 1

zoobank.org/215CAF7C-519D-442B-B8B3-CFB3EB15B1BB
Etymology. After our friend the late Dr. Jean Gaudant, specialist on Cenozoic fishes.

Material. Holotype: MNHN.F.A53794, male (Figure 1). Allotype: MNHN.F.A53795, female (Figures 2, 4.1). Paratypes: MNHN.F.A53796, male; MNHN.F.A53797, female (Figures 5.1, 6.2); MNHN.F.A53798, female (Figures 3.1, 5.2); MNHN.F.A53799, male (Figure 4.2); MNHN.F.A53800, male (Figure 3.2) (all Nel leg.); MNT-06-880AB, female (?) (Figure 6.1).

Type horizon. Palaeocene, spongo-diatomite maar Paleolake.

Type locality. Menat, Puy-de-Dôme, France.

Diagnosis. Fore tibiae widened apically. Fore femora in male longer than in female.

Description. Large-sized, body covered with dense setation; apterous gerrids with elongate, slender body: males: smaller size $14.5 \mathrm{~mm}$, average length $15.8 \mathrm{~mm}$, larger size $18.0 \mathrm{~mm}$; females: smaller size $15.8 \mathrm{~mm}$, average length $16.3 \mathrm{~mm}$, larger size $17.0 \mathrm{~mm}$; average distance between meso-acetabulum $3.05 \mathrm{~mm}$ in males and $3.07 \mathrm{~mm}$ in females. Body and legs covered with dense setation. Head poorly preserved, but seemingly short. Eyes not discernible. Antennae only partly preserved in all specimens, first antennomere very long (average length $5.2 \mathrm{~mm}$ ), second antennomere much shorter, third and fourth mostly not preserved. Rostrum short and thick, not long enough to reach posterior margin of prosternum. Trichobothria could not be found on heads. Pronotum short and transverse, ca. $1 \mathrm{~mm}$ long, $2 \mathrm{~mm}$ wide (Figure 3.2). Mesonotum large and broad, ca. 4 $\mathrm{mm}$ long, $2 \mathrm{~mm}$ wide, metanotum distinct, with a medial suture, without secondary ridge. Forelegs long, average femur length $5.05 \mathrm{~mm}$ in males and $4.25 \mathrm{~mm}$ in females; tibia length $4.8 \mathrm{~mm}$ (both sexes together), broadened at apex; fore tarsus probably with two tarsomeres, broken at apex, together ca. $1 \mathrm{~mm}$ long, second tarsomere almost twice as long as first, pretarsal structures not preserved. Long and slender middle legs inserted laterally on thorax; middle femur length $12.9 \mathrm{~mm}$, middle tibia ca. $10 \mathrm{~mm}$ long, somewhat widened apically (in specimen MNT-06-880, width at base $0.2 \mathrm{~mm}$, in the middle $0.15 \mathrm{~mm}$, at apex $0.2 \mathrm{~mm}$ ). Hind legs as long as middle legs; hind femur length ca. $11 \mathrm{~mm}$ (both sexes together), tibia ca. $11 \mathrm{~mm}$. In all three leg pairs, femora and tibiae covered with short dark setae. Abdomen ca. $8.5 \mathrm{~mm}$ long, almost parallel-sided. Genital segments of the male are not seen in detail, but obviously symmetrical (Figure 4.2). Male pygophor can be seen in the paratype MNHN.F.A53799, apparently 

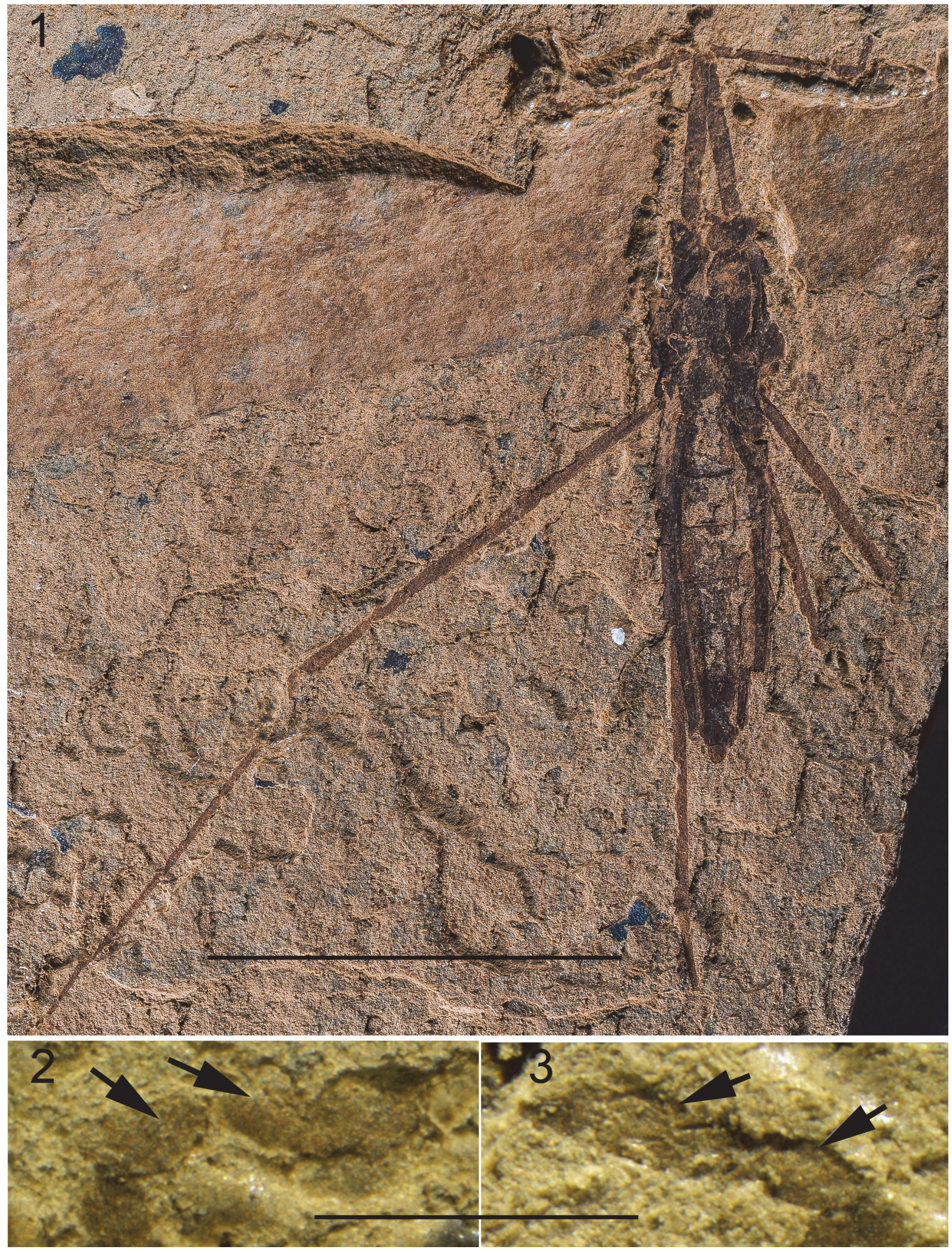

FIGURE 1. Habitus (1), left fore tarsus (2), and right fore tarsus (3) of Cylindrostethus gaudanti sp. nov. holotype, MNHN.F.A53794 (male). Arrows indicate tarsomeres. Scale bars equal $10 \mathrm{~mm}(1)$ and $1 \mathrm{~mm}(2,3)$. 

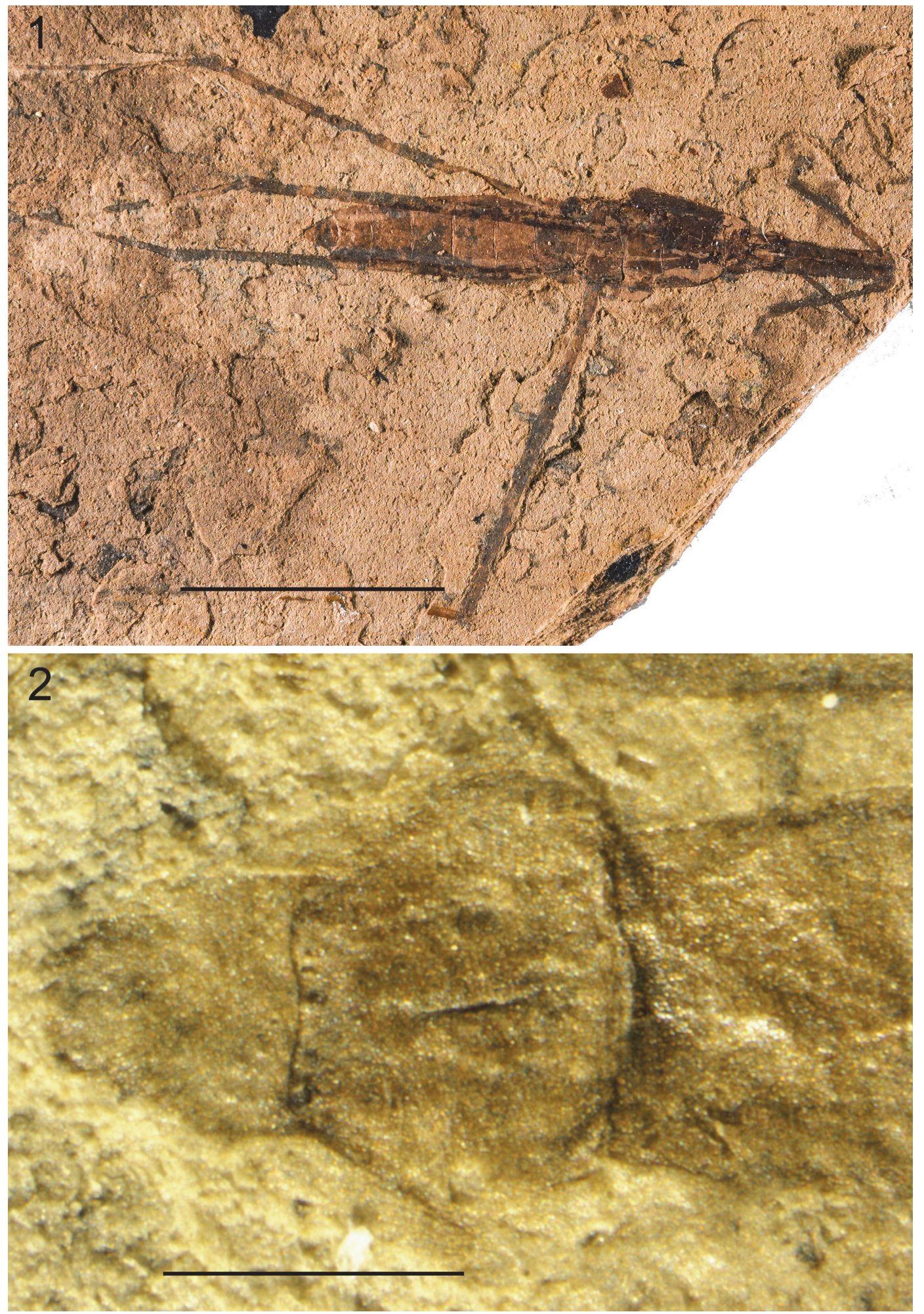

FIGURE 2. Habitus (1) and apex of abdomen (2) of Cylindrostethus gaudanti sp. nov. Allotype, MNHN.F.A53795 (female). Scale bars equal $10 \mathrm{~mm}(1)$ and $0.5 \mathrm{~mm}(2)$. 

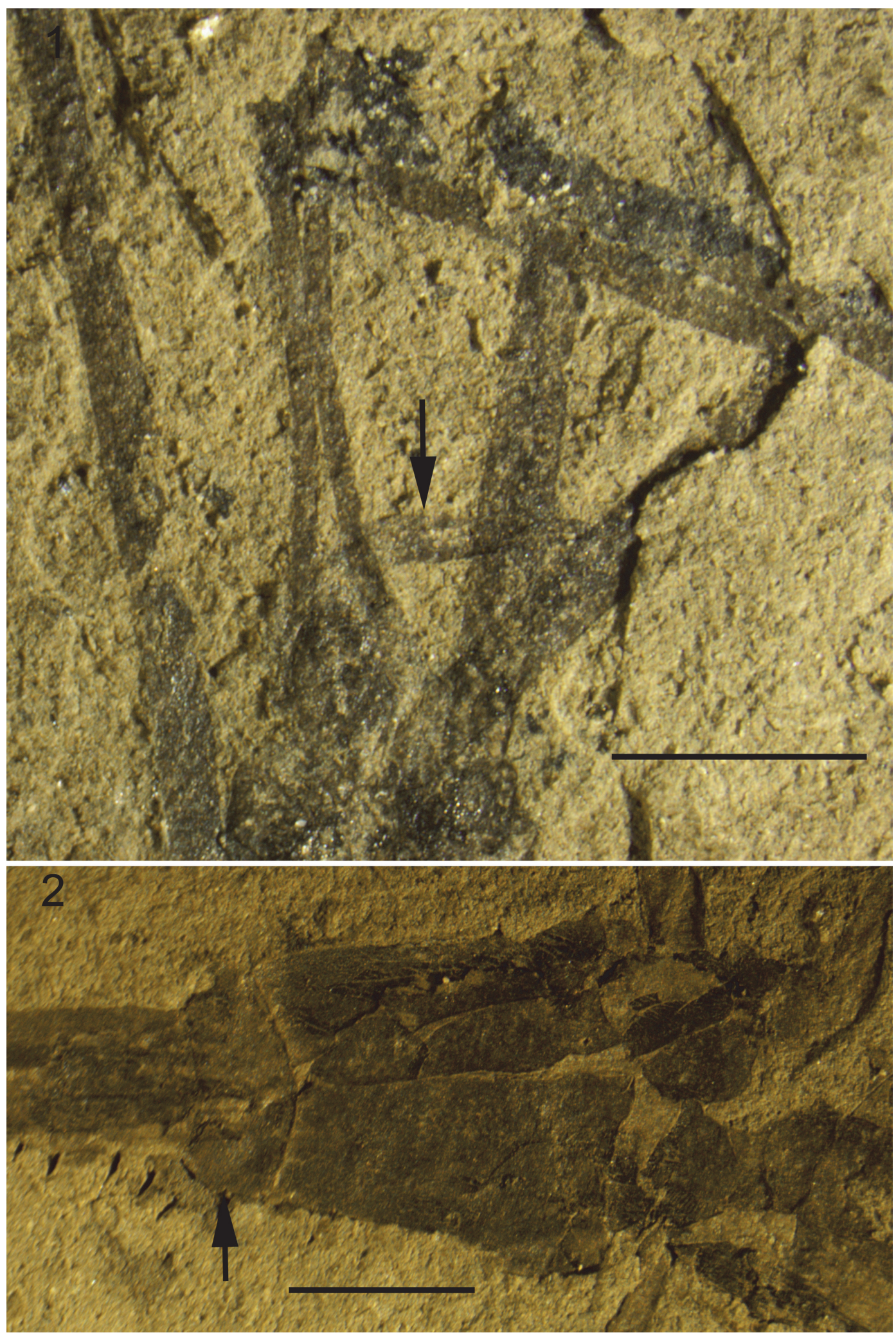

FIGURE 3. Head with rostrum (arrow) and antennae (1) and thorax (arrow: pronotum) (2) of Cylindrostethus gaudanti sp. nov. 1, MNHN.F.A53798 (paratype) and 2, MNHN.F.A53800 (paratype). Scale bars equal $2 \mathrm{~mm}$. 

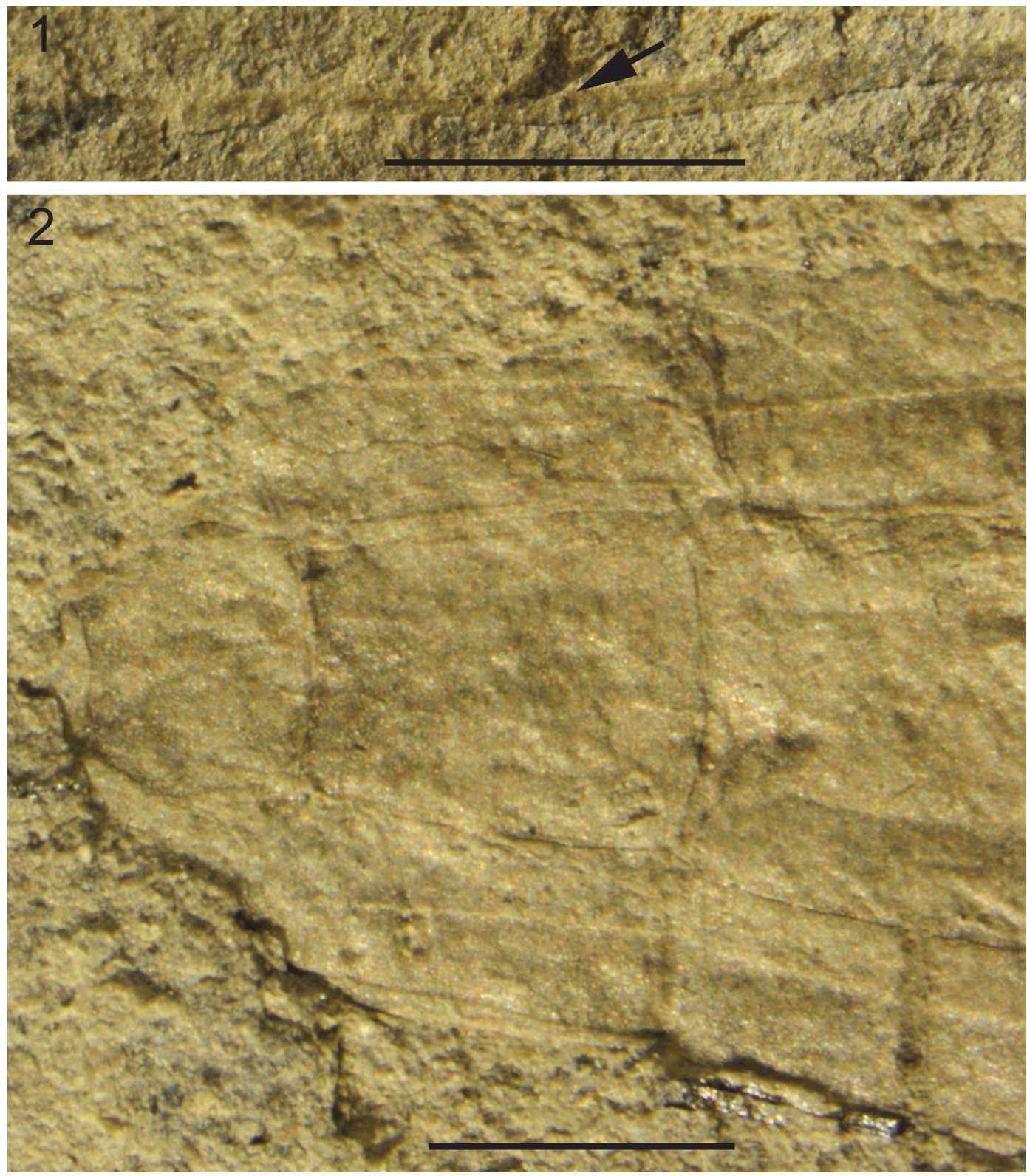

FIGURE 4. Apex of mid tibia (arrow) (1) and male terminalia (2) of Cylindrostethus gaudanti sp. nov. 1, MNHN.F.A53795 (allotype, female); and 2, MNHN.F.A53799 (paratype, male). Scale bars equal $1 \mathrm{~mm}$ (1) and $0.5 \mathrm{~mm}$ (2).

rounded. Female genital segments also symmetrical (Figure 2.2), average length $1.3 \mathrm{~mm}$, the first gonocoxites are well seen (Table 1).

\section{DISCUSSION}

Damgaard et al. (2014) noted that representatives of the subfamily Cylindrostethinae are among the gerrid subfamilies that can hardly be separated on the basis of the fossils. Damgaard (2008b) rejected Cylindrostethinae as paraphyletic, lending more support to the idea of Matsuda (1960) who considered Gerrinae in a broader sense, including some Andersen's (1982) subfamilies as tribes, Cylindrostetini among them. At the same time, Damgaard (2008b) admitted that the non-monophyly of Cylindrostethinae in his analysis is surprising since the female heavily sclerotized second gonapophyses and molecular data (mitochondrial 16S rRNA gene sequences) provided good apomorphies in previous studies. He mentioned insufficient taxon sampling for this subfamily, which could offer an explanation for the conflicting interpreta- 

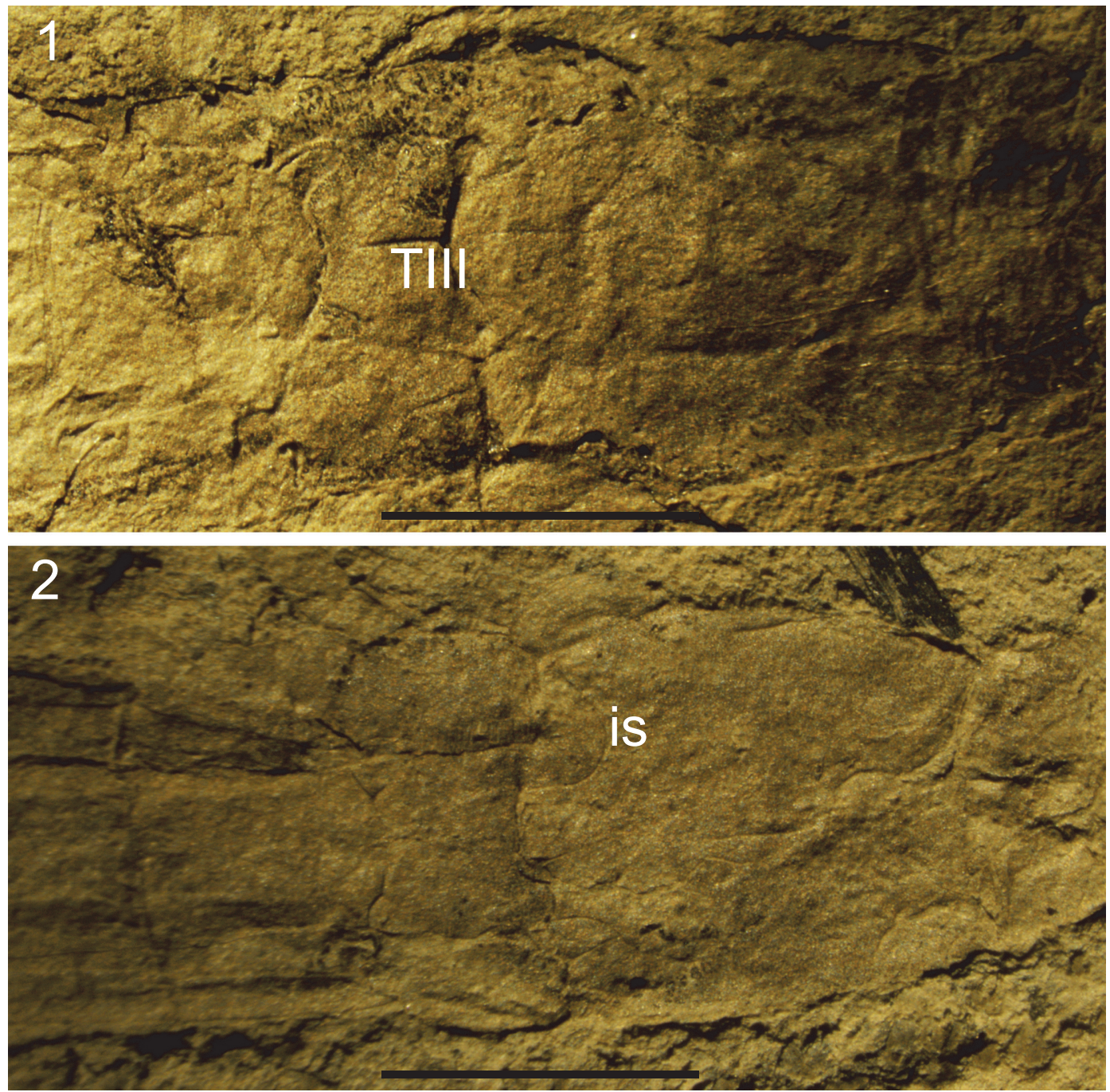

FIGURE 5. Thoraxes of Cylindrostethus gaudanti sp. nov. 1, MNHN.F.A53797 (paratype); and 2, MNHN.F.A53798 (paratype). Abbreviations: is, primary intersegmental suture between meso- and metathorax; TIII, metathorax. Scale bars equal $2 \mathrm{~mm}$.

tions. Our specimens fit the Cylindrostethinae data matrix of Damgaard (2008b) in the few characters that are observable in the fossil.

The pronotum short, not extended into a long pronotal lobe excludes affinities with the Gerrinae and Charmatometrinae. The character "rostrum (labium) short and robust, its apex not surpassing prosternum" present in our fossils, is shared by the Cylindrostethinae, Ptilomerinae, Halobatinae, and Rhagadotarsinae. Affinities with the Rhagadotarsinae are excluded because the female ovipositor in our fossils is very short unlike in Rhagadotarsinae. The short fore tarsus, clearly shorter than one-half the length of the tibia excludes affinities with the Ptilomerinae. The metasternum of normal size, not reduced, excludes affinities with the Halo- batinae. On the other side, the first segment of fore tarsus less than one-half the length of the second segment is a character of the Cylindrostethinae. The absence of a secondary transverse line on metanotum excludes affinities with the Electrobatinae (Andersen and Poinar, 1992; Andersen, 2000), while this character is shared by the Cylindrostethinae. Andersen (1982) characterized the Cylindrostethinae by two apomorphies "middle tibia and tarsus flattened" and "second gonapophyses heavily sclerotized". The second character could not be observed in our fossils, but the distally widened middle tibia are clearly seen. Fore tibiae are widened at the apex too, which is a distinctive character for the new species. 

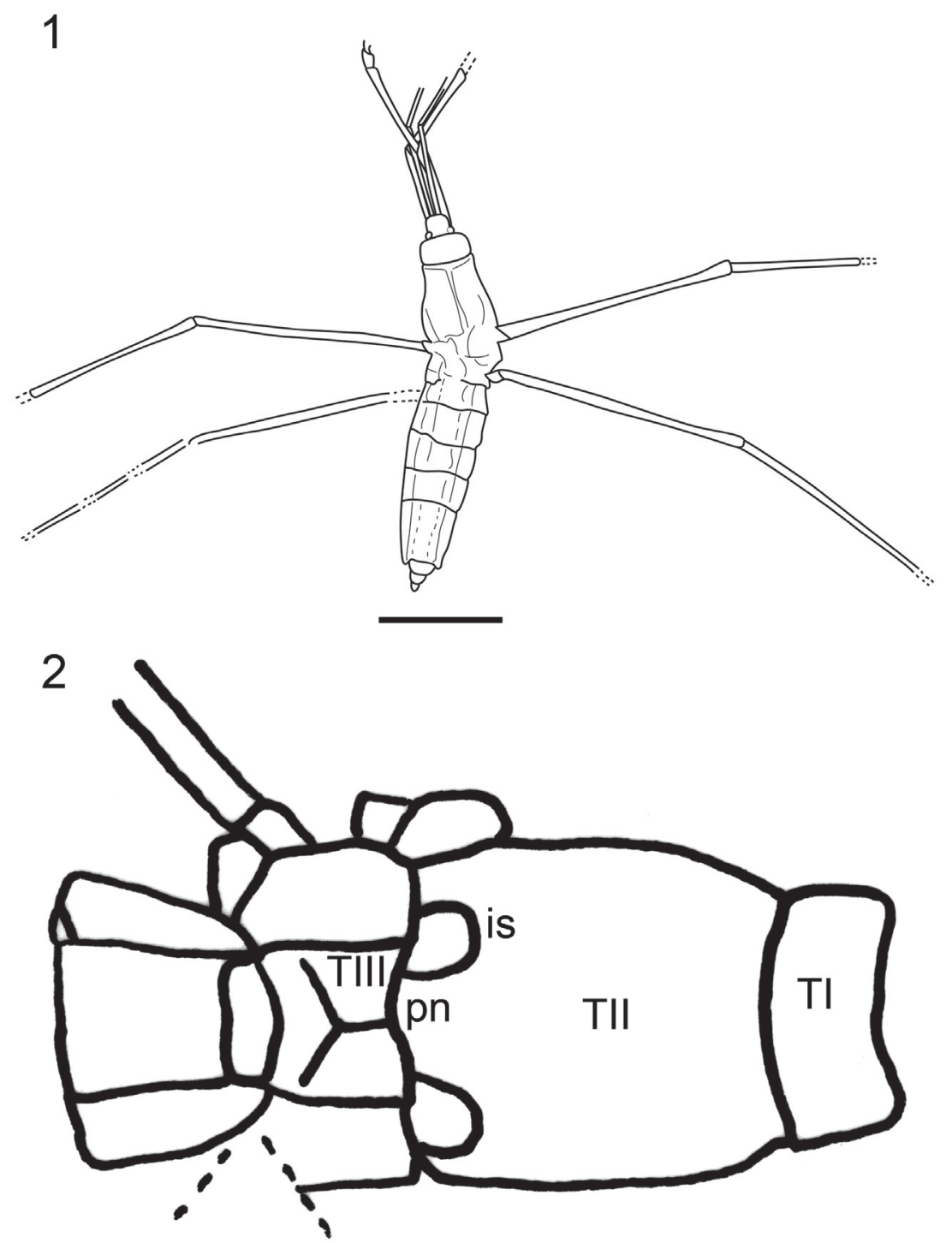

FIGURE 6. Reconstruction of Cylindrostethus gaudanti sp. nov. 1, body of MNT-06-880B (paratype); and 2, thorax of MNHN.F.A53797 (paratype). Abbreviations: is, primary intersegmental suture; pn, mesopostnodal margin; TI, pronota; TII, mesonota; TIII, metanota. Scale bars equal $5 \mathrm{~mm}$ (1) and $2 \mathrm{~mm}$ (2).

Within the Cylindrostethinae, our fossils fit in the genus Cylindrostethus rather than in the two other genera currently in this subfamily, because Platygerris has a body strongly flattened and a short abdomen (Matsuda, 1960), while Potamobates has a broader mesothorax, the male genitalia generally rotated and a short abdomen (Hungerford, 1937; Padilla-Gil and Damgaard, 2011). Lastly the Eocene Cylindrobathes differs from our fossils in the short fore legs, distinctly shorter than antennae, although its general habitus resembles that of our fossils (Wappler and Andersen, 2004).

Although the sample is poor (four male and two female measurements) and the fossils are compressed, the fore femora in the males are clearly bigger than in females $(5.05 \mathrm{~mm}$ against $4.25 \mathrm{~mm}$ ). This is more striking if we consider that the average body size of females is larger (16.3 to $15.8 \mathrm{~mm}$ ). The larger fore femur could thus be a 
TABLE 1. Measurements (in $\mathrm{mm}$ ) of the specimens examined in this study. Blank cells show lacking body parts. In paired extremities, if both counterparts were present, still only the best preserved one of them was measured. Except for the body length, indicated dimensions correspond to the lengths.

\begin{tabular}{|c|c|c|c|c|c|c|c|c|c|c|c|}
\hline Specimen & $\begin{array}{l}\text { Body } \\
\text { length }\end{array}$ & $\begin{array}{l}\text { Body } \\
\text { width }\end{array}$ & $\begin{array}{c}\text { 1st antennal } \\
\text { segment } \\
\text { length }\end{array}$ & $\begin{array}{l}\text { Fore } \\
\text { femur } \\
\text { length }\end{array}$ & $\begin{array}{c}\text { Fore } \\
\text { tibia } \\
\text { length }\end{array}$ & $\begin{array}{l}\text { Fore } \\
\text { tarsus } \\
\text { length }\end{array}$ & $\begin{array}{l}\text { Middle } \\
\text { femur } \\
\text { length }\end{array}$ & $\begin{array}{c}\text { Middle } \\
\text { tibia } \\
\text { length }\end{array}$ & $\begin{array}{l}\text { Hind } \\
\text { femur } \\
\text { length }\end{array}$ & $\begin{array}{c}\text { Hind } \\
\text { tibia } \\
\text { length }\end{array}$ & $\begin{array}{l}\text { Genitali } \\
\text { length }\end{array}$ \\
\hline \multicolumn{12}{|l|}{ Male } \\
\hline A53794 & 14.5 & 2.5 & & 5.0 & 4.4 & 1.1 & 13.3 & 9.7 & 8.0 & & ca. 0.9 \\
\hline A53799 & 15.7 & 3.3 & & 5.0 & & & 12.7 & & 11.7 & & \\
\hline A53796 & 15.0 & 3.2 & 6.0 & 5.0 & 4.7 & & 15.4 & & & & \\
\hline A53800 & 18.0 & 3.2 & 5.0 & 5.2 & 5.1 & & 12.4 & & 10.3 & 11.0 & \\
\hline \multicolumn{12}{|l|}{ Female } \\
\hline A53795 & 17.0 & 3.4 & & 4.0 & 4.5 & 1.0 & 12.8 & 11.0 & 12.0 & 11.0 & 1.3 \\
\hline \begin{tabular}{|l|} 
A53798 \\
\end{tabular} & 16.0 & 2.7 & 4.6 & 4.5 & 5.3 & & 11.0 & & 12.8 & & 1.5 \\
\hline A53797 & 15.8 & 3.1 & & & & & & & & & 1.1 \\
\hline
\end{tabular}

sexually dimorphic character in this species, although this hypothesis needs to be tested on more specimens.

The Cylindrostethinae is a tropicopolitan subfamily, with Potamobates present from Mexico to Peru, Platygerris is a South and Central American in distribution, and Cylindrostethus is distributed in South America, Africa, and South-East Asia (Andersen, 1982). It is practically impossible to compare with the different modern species of this genus because of the incomplete preservation of the abdomen and genitalia (Matsuda, 1960). Its presence in the Paleocene of the Central France supports a wider distribution in the past and explains it modern disjunct distribution. Also the palaeoecology of the outcrop (a rainforest surrounding a small lake connected to rivers) fits with the habitat of the modern Cylindrostethus (Polhemus, 1994).

\section{ACKNOWLEDGEMENTS}

We thank two anonymous referees for the useful remarks on the first version of the paper. We sincerely thank the town of Menat for the loan of the specimen MNT 06 880AB. We also thank our colleague S. Pont for the SEM images.

\section{REFERENCES}

Andersen, N.M. 1982. The semiaquatic bugs (Hemiptera: Gerromorpha): phylogeny, adaptations, biogeography and classification. Entomonograph, 3:1-445.

Andersen, N.M. 1998. Water striders from the Paleogene of Denmark with a review of the fossil record and evolution of semiaquatic bugs (Hemiptera, Gerromorpha). Det Kongelige Danske Videnskabernes Selskabs Biologiske Skrifter, 50:1-157.

Andersen, N.M. 2000. Fossil water striders in the Oligocene/Miocene Dominican amber (Hemiptera: Gerromorpha). Insect Systematics and Evolution, 31:411431.

Andersen, N.M. and Poinar, G.O. Jr. 1992. Phylogeny and classification of an extinct water strider genus (Hemiptera, Gerridae) from Dominican amber, with evidence of mate guarding in a fossil insect. Zeitschrift für Zoologische Systematik und Evolutionsforschung, 30:256-267.

Damgaard, J. 2008a. Evolution of the semi-aquatic bugs (Hemiptera: Heteroptera: Gerromorpha) with a reinterpretation of the fossil record. Acta Entomologica Musei Nationalis Pragae, 48:251-268.

Damgaard, J. 2008b. Phylogeny of the semiaquatic bugs (Hemiptera-Heteroptera, Gerromorpha). Insect Systematics \& Evolution, 39:431-460.

Damgaard, J., Moreira, F.F.F., Weir, T.A., and Zettel, H. 2014. Molecular phylogeny of the pond skaters (Gerrinae), discussion of the fossil record and a checklist of species assigned to the subfamily (Hemiptera: Heteroptera: Gerridae). Insect Systematics \& Evolution, 45:251-281. 
Hungerford, H.B. 1937. A new Potamobates from Mexico (Hemiptera Gerridae). Journal of the Kansas Entomological Society, 10:63-65.

Leach, W.E. 1815. Entomology. p. 57-172. In Brewster, D. (ed.), The Edinburgh Encyclopaedia, vol. 9. Blackwood, Edinburgh.

Matsuda, R. 1960. Morphology, evolution and a classification of the Gerridae (Hemiptera - Heteroptera). University of Kansas Science Bulletin, 41:25-632.

Mayr, G.L. 1865. Diagnosen neuer Hemipteren. Verhandlungen der Kaiserlich-Königlichen Zoologisch-Botanischen Gesellschaft in Wien, 15:429-446.

Michon, L. 2000. Dynamique de l'extension continentale - Application au Rift Ouest-Européen par l'étude de la province du Massif Central. PhD Thesis, Université Blaise Pascal Clermont II, France.

Michon, L. and Merle, O. 2001. The evolution of the Massif Central rift, spatio-temporal distribution of the volcanism. Bulletin de la Société Géologique de France, 172:201-211.

Padilla-Gil, D.N. and Damgaard, J. 2011. A new species of Potamobates Champion from Colombia with a reanalysis of phylogenetic relationships (Hemiptera: Gerridae). Zootaxa, 2879:41-49.

Perrichot, V., Nel, A., and Néraudeau, D. 2005. Gerromorphan bugs in Early Cretaceous French amber (Insecta: Heteroptera): first representatives of Gerri- dae and their phylogenetic and palaeoecological implications. Cretaceous Research, 26:793-800.

Piton, L. 1940. Paléontologie du gisement éocène de Menat (Puy-de-Dôme), flore et faune. Mémoire de la Société d'Histoire Naturelle d'Auvergne, 1:1-303.

Polhemus, D.A. 1994. Taxonomy, phylogeny, and zoogeography of the genus Cylindrostethus Fieber in the Paleotropical region (Heteroptera: Gerridae). Bishop Museum Occasional Papers, 38:1-34.

Popov. Yu.A. 1971. Origin and main evolutionary trends of Nepomorpha bugs. 13th International Congress of Entomology, 1:282-283.

Vincent, P.M., Aubert, M., Boivin, P., Cantagrel, J.M., and Lenat, J.F. 1977. Découverte d'un volcanisme paléocène en Auvergne, les maars de Menat et leurs annexes; étude géologique et géophysique. Bulletin de la Société Géologique de France, 19:1057-1070.

Wappler, T. and Andersen, N.M. 2004. Fossil water striders from the Middle Eocene fossil sites Eckfeld and Messel, Germany (Hemiptera, Gerromorpha). Paläontologische Zeitschrift, 78:41-52.

Wappler, T., Currano, E.D., Wilf, P., Rust, J., and Labandeira, C.C. 2009. No post-Cretaceous ecosystem depression in European forests? Rich insect-feeding damage on diverse middle Palaeocene plants, Menat, France. Proceedings of the Royal Society London, 276:4271-4277. 